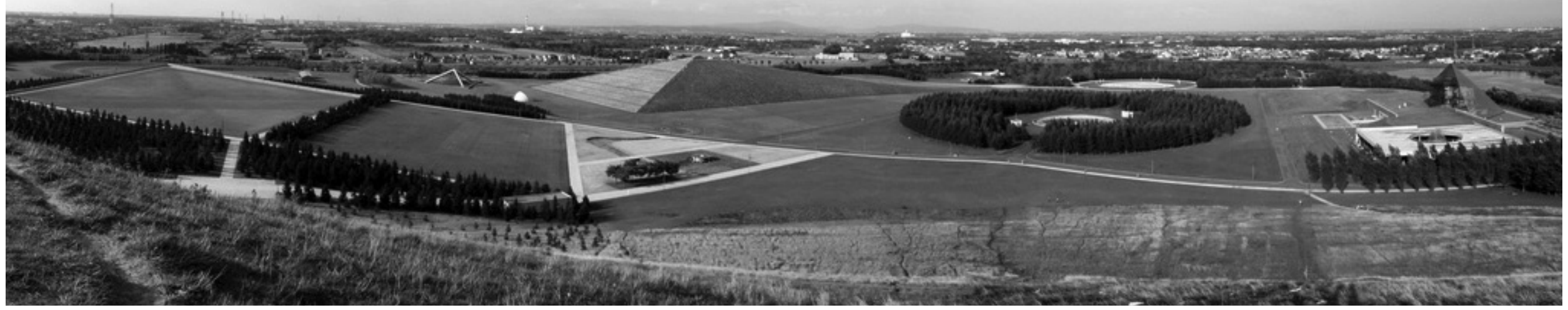

A Fig.1 Parque Moerenuma en Higashi-ku, Sapporo. Isamu Noguchi

\title{
Arquitectura es paisaje Una expedición a la arquitectura como punto de encuentro
} Josep Ferrando

El pasado mes de septiembre la ciudad de Tokio albergó el $24^{\circ}$ Congreso Mundial de Arquitectura de la Unión Internacional de Arquitectos, una, cita trienal que, bajo el lema "Diseño 2050", abordó diferentes objetivos de la arquitectura en conferencias, talleres, exposiciones y debates.

Con motivo de este evento, el Instituto Cervantes de Tokio y el Colegio de Arquitectos de Hokkaido invitaron a un grupo de arquitectos catalanes a realizar una serie de eventos bajo el título "Arquitectura es paisaje". Esta colaboración se tradujo en una exposición, una serie de conferencias y un debate con la presencia del arquitecto japonés Kengo Kuma.

Para una parte del grupo fue una ocasión para descubrir un territorio y para otros fue una ocasión para mirar con detenimiento aquello que ya se conocía; nos tomamos el viaje como una exploración, como una oportunidad de aprendizaje y de adquisición de nuevo conocimiento.

Una oportunidad para conocer los intereses y las preocupaciones de otras culturas y poder, en definitiva, compararla activamente con nuestra manera de trabajar

La Arquitectura como lugar de encuentro entre la naturaleza y el hombre; como umbral entre el ámbito público y el ámbito privado; y como punto de diálogo entre las personas.

\section{Entre la Naturaleza y el Hombre}

Japón es un país que surgió del mar, un archipiélago que, por su orografía y su relieve volcánico, concede a la naturaleza un papel protagonista, lo que determina un profundo amor y respeto por ella. La presencia del agua es constante, incluso, simbólicamente, en un jardín seco como en Ryoanil.

El grabado Ukiyo-e (pintura del mundo flotante) realizado por Hokusai y extraído del libro "Cien vistas del Monte Fuji") (fig.2), representa la figura de un literato observando el Monte Fuji y ejemplifica de forma clara la relación con el lugar. Como define Asai Ryoi en Cuentos sobre Mundo Flotante: "viviendo placeres de la luna la nieve, los cerezos en flory las hojas de los arces; cantando canciones, bebiendo vino, divitiéndonos nosotros mismos solo flotando, flotando; sin dejar un ápice de gesto paupérrimo en nuestra cara, rehusando estar desalentados, como una calabaza deslizando por la corriente de un río: esto es lo que llamamos Mundo Flotante".

La cultura tradicional japonesa se basa en el ideal de belleza, entendida esta como el encuentro del hombre y la naturaleza. El poeta de haiku Matsuo Bashô (1644-1694) es capaz de comprimir en sólo tres versos dicha esencia:
Furuike ya
kawazu tobikom
Un viejo estanque
mizu no oto
Se zambulle una rana

La Arquitectura debería ser el ruido del agua, el sonido de la naturaleza cuando recibe la acción del hombre; debería ser la traducción de un estado de relación donde la modificación del lugar no acabe por contradecirlo.

El parque Moerenuma (fig.1), situado sobre una antigua planta de tratamiento de residuos, refleja el ideal de sociedad de Noguchi: un lugar donde no hay un sentido de la especificidad pero sí un sentido de universalidad.

2. Entre el ámbito público y privado

El trabajo de Issey Miyake está marcado profundamente por la experimentación, llegando a trascender el mundo de la El ñ̃o 1999 Issey Miyake diseñó la colección Jumping (fig.3). En ella los vestidos tienen su propia estructura, no responden a la del cuerpo humano marcada por la columna vertecírcus extremidades, y serfil irregular. El sistema genera una geometría que dista del perfil de la persona, moldeando el es-

pacio que más interesa a Issey, el vacío entre ambos. El cuerpo queda liberado dentro de la prenda y se establecen relaciones a ravés de los espacios intermedios.

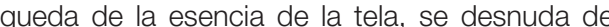
otones y costuras, logrando su propia naturalidad.

La casa tradicional japonesa era una vivienda larga de fachada corta donde la parte frontal correspondía tradicionalmente a la tienda, o a una área social cuando la vivienda no tenía actividad comercial: un espacio que pertenecía al ámbito privado pero con carácter público, el lugar intermedio que desdibujaba el límite entre ambos. A continuación se encontraba la parte de la vivienda, construida sobre una trama de columnas rectangulares de madera divisible por paneles móviles.

a fachada de la casa se recubría con un entramado de madera que identificaba la actividad del comercio y añadía un filtro más, de nuevo en relación con el exterior.

La casa de té es una cabaña a la que se accede por una pequeña puerta a través de la cual los invitados entran de rodillas, dejando cualquier tipo de arrogancia y jerarquía fuera.

La Arquitectura debería nutrirse de espacios intermedios, umbrales de transición que moldeen nuestro estado en el recorrido de aproximación a un lugar.

La casa del arquitecto Akasaka Shinichiro, situada a las afueras de Sapporo, es un cuerpo de dos plantas que se ancla a la pendiente de la colina (fig.4). Un volumen simple y claro que explora la sensación espacial mediante sútiles modificaciones. En el interior, el vacio de planta triangular permite relacionar e comedor con la sala de estar y prolongarse hacia el bosque que la rodea, desdibujando los límites físicos entre interior y exterior.

\section{Entre las personas}

En Japón, las relaciones personales están muy influenciadas por las ideas de "honor", "obligación" y "deber"; es una sociedad "colectivista", muy lejos de la cultura individual y liberal. Los japoneses siempre intercambian cualquier objeto con ambas manos, mostrando una actitud de respeto y gratitud, en un acto de ofrecer. Esta actitud concede valor a todo el proceso de trabajo y a las personas que han intervenido en él, a quien ofrece y a quien recibe.

Toda esta coreografía de gestos se transforma en una manera de pensar y de producir, donde el silencio toma valor expresivo (fig.5). Carles Martí, en su libro Silencios Elocuentes, se refiere al cine de Yasujirô Ozu con las siguientes palabras: "Hay un rasgo peculiar, característico del cine de Ozu, que algunos han considerado la clave de su poética. Se trata de los célebres planos vacíos en los que aparecen visiones estáticas de objetos inanimados, a modo de naturalezas muertas, o bien imágenes de interiores vacíos (..) si lo miramos con atención, nos damos cuenta que actúan como receptáculos de los sentimientos que el film suscita en nosotros(...) se subraya la importancia de lo que no se dice, de lo que no acontece. De este modo se revelan las huellas de lo ausente".

La Arquitectura debería contener silencios, y debería construirse como las relaciones: atendiendo y ofreciendo al contexto.

Cena ofrecida por el Colegio de Arquitectos de Hokkaido. Como signo de cortesía la cena empieza con el intercambio de tarjetas de presentación, Meishi en japonés. Este ritual se convierte en el momento más importante de interrelación y esrecibirla cogiendola por las puntas y pararse unos segundos a leer detenidamente la información que hay en ella, ya que en La Arquitectura es paisaje cuando lee y observa la información del lugar que la precede.

Josep Ferrando es arquitecto por la E.T.S.A.B., donde actualmente es profesor de Proyectos Arquitectónicos. También imparte clases en la Escuela de Arquitectura de La Salle, en la University of Illinois at Chicago, en el Istituto Europeo de Design y en la Escola de Disseny i Art Eina.

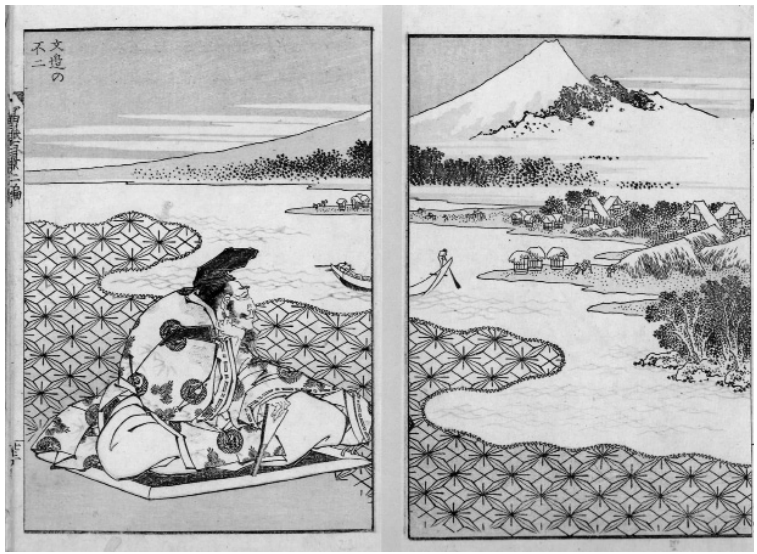

Fig.2 Hokusai, Ukiyo-e

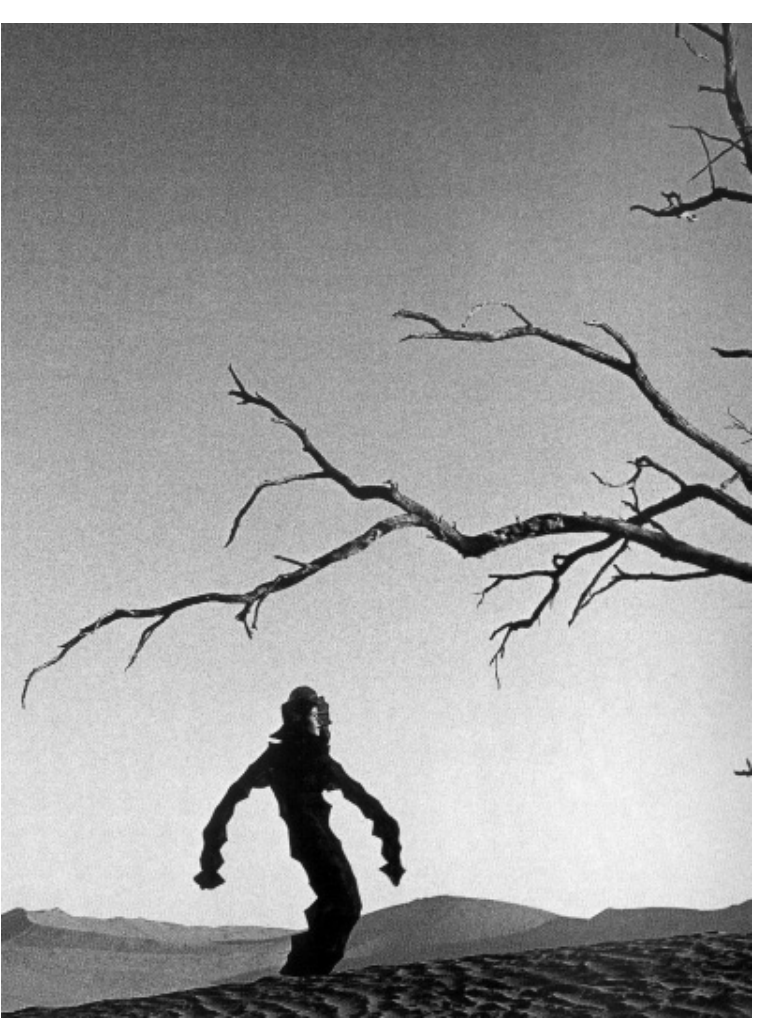

Fig.3 Issey Miyake. colección Jumping

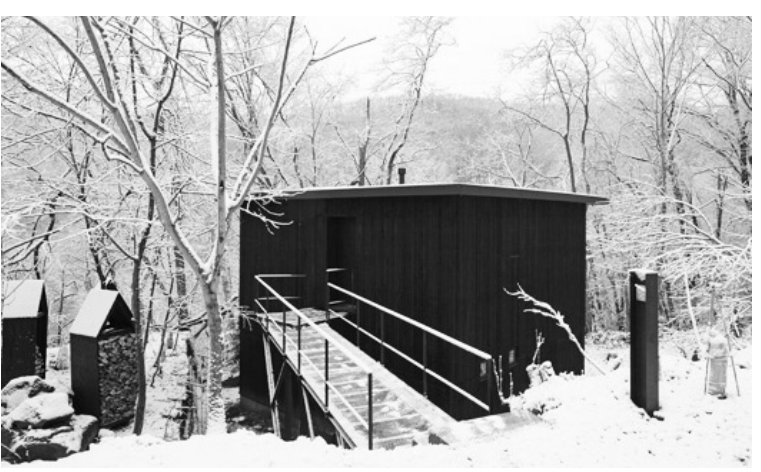

Fig.4 Akasaka Shinichiro. Casa del arquitecto

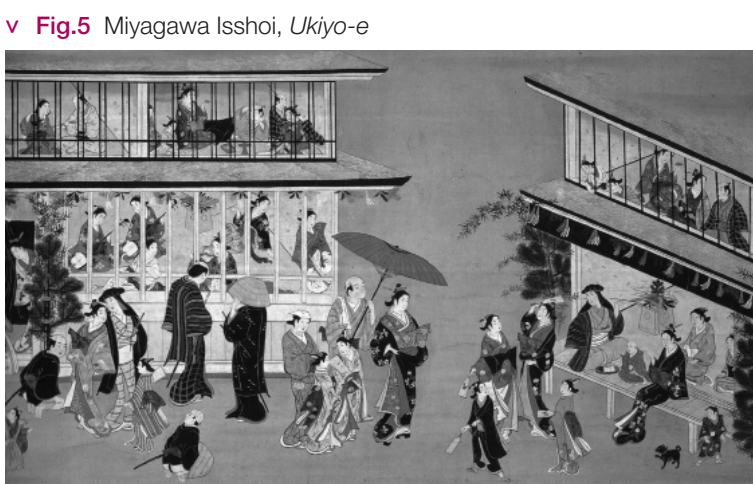

